\title{
Livestock production systems, subsidies and its implications: An investigation through review of literature
}

\author{
BS Chandel, Priyanka Lal and Binita Kumari
}

Received: 18 January 2019 / Accepted: 22 January 2019 / Published online: 18 April 2019

(C) Indian Dairy Association (India) 2019

\begin{abstract}
In the process of development, among different agricultural subsectors, livestock is one of the fastest growing sectors, and this subsector has been provided various incentives in the form of subsidy and support. This paper summarizes the findings of the past studies on livestock production systems, subsidies and its implications which were constrained by the limited literature available covering all the aspects. In livestock sector, subsidies have been provided on investment, purchase of animals, feed and insurance. There is no doubt that subsidies have well served its short term objectives, nevertheless, it has had adverse effects on environment and economic efficiency in the long run such as over-exploitation of fish stock, grazing lands and soil degradation. Finally the paper comes out with information gaps on the topic that required to be addressed.
\end{abstract}

Keywords: Livestock production system, Subsidy, Review

\section{Introduction}

The role of livestock production system dominates world over in all the three broad classes of economies. According to UN (2014), all countries of the world have been classified into one of three broad categories: developed economies, economies in transition and developing economies. In developing economies, due to

BS Chandel( $₫)$, Priyanka Lal and Binita Kumari

Division of Dairy Economics, Statistics and Management, ICAR-National

Dairy Research Institute, Karnal-132 001, Haryana, India

E-mail: chandelbs@rediffmail.com resource poor nature of the farmers, livelihood is mainly derived from pastoral and nomadic type of livestock production system; while livestock is an integral part of agrarian economies in transition and in developed economies, demand moves in favour of livestock products especially meat/ beef. Currently, livestock is one of the fastest growing agricultural subsectors in developing countries (Thornton, 2010). It has been characterized as highly dynamic and evolving in response to rapidly increasing demand for livestock products (Steinfeld and Maki-Hokkonen, 1995).

Thus, in the process of development, the structural changes in the livestock production system goes on taking place which are supported by institutional reforms and kind of incentives provided to the sector with certain objectives in mind to achieve. This paper attempts to summarize the findings of the past studies on livestock production systems, purpose of subsidies, its implications in the sector on overall livelihood of farmers and environment. The resorting to review of literature methodology was necessitated due to inadequate data available world over on livestock parameters and especially in developing and economies in transition like India. The study has been limited by the observation that despite the importance of this sector in the economies, very few research studies were exclusively focused on livestock subsidy. On the basis of available literature, this paper has been organized into three parts namely (1) livestock production systems and structural changes, (2) target, level and extent of livestock subsidy, and (3) implications of subsidy.

\section{Livestock production systems and structural changes}

Livestock production systems are basically a subset of farming systems (Ruthenberg, 1980, Wilson, 1994) within the agriculture sector. A type of livestock production systems that prevails in developed and developing economies is evolving in response to rapidly increasing demand for livestock products. The justification for applying a concept of livestock production systems lies in its usefulness for livestock development (Jahnke, 1982). Characterization is the grouping of farmers with similar practices and circumstances for whom a given recommendation would be broadly appropriate (Byerlee et al 1980). The past studies have identified resource endowments, production and market 
variables (William, 1994; Staal et al., 1998), agro-climatic conditions (Jahnke, 1982, Steinfeld et al. 2006, Sere and Steinfeld, 1996) and regional dimensions (Steinfeld and Maki-Hokkonen, 1995) as criteria to define livestock systems. Majority of the studies has used these criteria for classifying the livestock production systems. This classification was further improved by considering the additional criteria of commercialization or intensification of production (Markemann et al, 2010, Teufel et al., 2010). In western Niger, cluster and discriminant analysis were used to classify crop-livestock producers using a combination of production and marketing variables (Williams 1994).

A comprehensive exercise on classification of livestock production systems at global level was conducted by Sere and Steinfeld (1996) in which eleven systems were defined based criteria -integration with crops, relation to land, agro-ecological zone, intensity of production, and type of production data, used in sequence.

This system consists of landless production system, which has subsystem of ruminant and monogastric production systems (chicken and pig). Based on the farm produced dry matter fed to animals further classification was made into grassland based system, mixed farming system, rainfed mixed farming system and irrigated mixed farming system. These systems were further sub classified and had subsystem of temperate and tropical highland, humid/sub-humid and sub-tropics and arid/semi-arid tropics and sub-tropics. The study concluded that mixed rainfed temperate and tropical highlands system alone produces more than half (55.5 per cent) of total milk production from all considered species and 62.6 per cent of cow milk production. South Asia and EU-25 are the most important dairy regions, accounting for 44 percent of global milk production (Hemme \& Otte, 2010). The mixed farming is closely related to agro-climatic zones and cropping pattern of the land because livestock element is interwoven with crop production as in rice/buffalo or cereal/cattle systems (Steinfeld et al. 2006).

The landless system is characterized as intensive production system and stated to be observed in developed countries because these countries tend to be substantially better endowed with land and livestock per inhabitant whereas in developing countries mixed farming systems were dominant (Steinfeld and MakiHokkonen, 1995). For instance, in OECD member countries, monogastric system is predominantly 52 percent of total landless pork production and 58 percent of the landless poultry production globally. In case of ruminant species, cattle intensive dairy production is followed. These are exclusively found in Eastern Europe, CIS, and in a few OECD member countries (Steinfeld and Maki-Hokkonen, 1995). These systems are feed intensive and labour extensive. The number of livestock units (LUs) tripled in China in less than 30 years, mainly through the growth of landless industrial livestock production systems and the increase in monogastric livestock (from 62 to $74 \%$ of total LUs) (Bai et al., 2018).

\section{Regional Specificity and resource endowments}

The global livestock sector is characterized by a dichotomy between developing and developed countries (Thornton, 2010). There is huge difference in livestock production system among Africa, Asia and Europe continents, not only because of resource endowments but also other factors like difference in demand, agro-climatic conditions and government support. Nevertheless, it may be noted that the evolution and development of farming systems does not recognize country borders and livestock farming systems are not always distributed in tight correlation with cropping systems as is the case rural landless livestock system. Steinfeld and Maki-Hokkonen, 1995 has grouped livestock systems to regions like Sub-Saharan Africa, Asia, Central and South America, West Asia, North America, OECD, Common Wealth and independent states. In Tropical Africa, Jahnke, 1982 coupled farming system and ecological zones to describe range, crop-livestock (lowland and highland), ranching and landless production system. The author elaborated that pastoral range livestock production system predominates in arid zone and as the zone become more humid, crop livestock system is followed and in labour extensive regions, ranching is followed. In the Lake Crescent Region of Uganda, a variety of peri-urban smallholder dairy farm types were identified (Fonteh et al 2005). The most common (representing about $70 \%$ ) was characterized by limited land availability ( $<2$ acres), located at the outskirts of town (between approximately 5 and $10 \mathrm{Km}$ away from town) and five or less cows.

Staal et al., 1997 used cluster analysis to characterize dairy systems in Kiambu (Kenya) on the basis of level of intensification, household resources and access to services and markets. The analysis distinguished four main groups of dairy farms namely informal resource poor, cooperative resource poor, the elite and the specialists. The former two systems were mainly the resource poor farmers supplying milk to informal and formal (cooperatives) markets. In a continuous study (Staal et al., 2001), the authors observed rapid intensification of smallholder dairy production that is occurring in the central part of Kenya apparently as a result mainly of shrinking land holdings. Over the last ten years farms have shifted increasingly to the use of stall-feeding and to planting of fodder, and now rely less on natural fodder. Milk production systems in Kenya vary widely with breeds of animals used, intensity of land and labor use and feeding systems in Kenya (Wakhungu 2001; Muriuki et al 2003).

In Asia, livestock is practiced as an integral part of cropping system. Teufel et al., 2010 used subsistence and commercial as additional parameters to classify the livestock production system in Asia and Greater Mekong Sub-Region. The study found that mixed irrigated, arid and semi-arid systems dominate in India, 


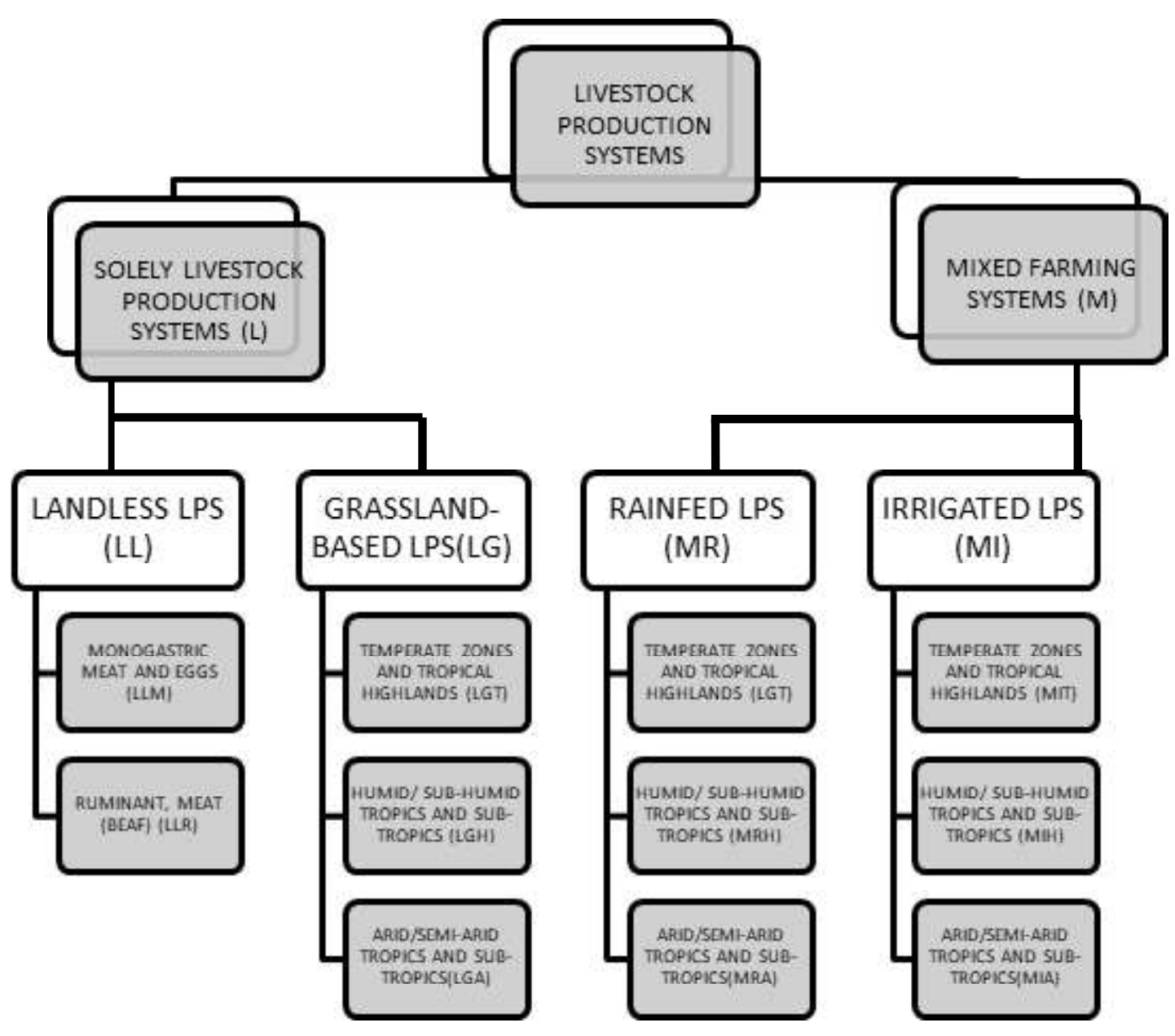

Source: Sere and Steinfeld (1996)

Pakistan, Nepal, Vietnam and Thailand whereas the livestock production system in Sri Lanka, Bangladesh and Cambodia is mixed rainfed humid and semi-humid. Study found that landless intensive production system is growing in Asia. The landless monogastric system is important in Southeast and eastern Asia; about 96 per cent of the total pig-meat production in Asia occurs in China, Vietnam and Indonesia whereas China, Thailand and Malaysia produce 84 per cent of poultry meat through this system. Whereas, the landless ruminant system, it is found only in Asia and Africa. The increase in demand for animal-source food is important for many reasons for the intensification of livestock production in developing countries continues to grow (Robinson, 2011). The small holder milk production system in India and in other Asian regions is part of mixed livestock production system. In the period 2002 to 2007 , world milk production grew by 13 percent mainly through production increases in China, India and Pakistan, which rely predominantly on smallholder dairy production systems and have increased their share in world milk production (Hemme \& Otte, 2010).

\section{Structural changes/institutional reforms}

In Asia, there is characteristic reduction of farm families raising cattle and pigs (Sugiyama et al., 2003). But in countries like Bangladesh, Pakistan and Mongolia, there was increasing number of household raising cattle. On the contrary, there was drastic reduction of families rearing cattle in countries like Japan and Korea. Steinfeld and Maki-Hokkonen, 1995 argued that increased demand for livestock products due to population growth and the rising per capita income in many areas of developing countries, incentives for intensification are growing since horizontal expansion is no longer a viable option for most countries.

By the end of 1970s in China, livestock in both pastoral areas and crop farming areas were distributed to individual herders and farmers which were earlier owned either by state farms or collectives. This reform process of the livestock sector was basically regarded as one of the privatization (Bingsheng, 2002). The main reason for this reform was low economic efficiency from high production costs and management problems resulting into large scale state pig and dairy cattle farms operate mostly at a loss. 


\section{Targeting, level and extent of subsidy}

Keeping in view the importance of livestock sector in the economy, different incentives have been provided by the government in the form of direct and indirect subsidy to bring about desired development in this sector. Direct subsidies are those which involves actual payment to an individual for a particular purpose, whereas indirect subsidies doesn't involve any direct payment but involve actual cash outlays or predetermined monetary value. Subsidies can have a major impact in augmenting welfare of the society provided these are designed and administered efficiently to serve a clearly stated set of objectives. However, subsidies can also be very costly if they are poorly designed and inefficiently administered (Srivastava, 2003). Therefore, targeting of subsidy is very important to have desired effects on the sector. The review of literature in this section is focused on objectives, level and extent of subsidy in livestock/ agriculture sector.

\section{Investment subsidy}

Investment to increase the supply had been the major reason for subsidy. The state owned farms in China were provided subsidy in order to establish them and then, to run them since they were operating at loss and the government considered sufficient supply of meat, milk and eggs to the urban population as crucial for social and political stability (Bingsheng, 2002). The author reported that the local government designated certain sites for livestock operations and granted investment subsidies either directly or through subsidized credit programs to farmers who move their livestock operation to those sites. This measure aims to attract farmers to abandon their backyard production system and thereby to reduce environmental problems in the villages (Bingsheng, 2002). In the same way, in order to boost the cattle population and to close meat deficiency in Turkey, the Government of Turkey grant calf subsidy. Indirectly, the calf subsidy was also aimed at shortening the calving period and targeting one calf in one year (USDA, 2016). The targeted extent of livestock subsidy in Turkey was 27.59 per cent $(\$ 1.07$ billion in total agriculture subsidy of $\$ 3.87$ billion) and the share of calf subsidy was as high as 31.25 per cent in total livestock subsidy (USDA, 2016).

\section{Subsidy targeted at Inputs}

Drucker et al., 2006 identified 15 types of subsidies given in Vietnam to the pig sector for rearing and purchase of breeding stock, for purchase of pigs and infrastructure, artificial insemination, water supply and treatment, export, feed, training and veterinary expenses. Generally, price support and subsidies focused on inputs results into intensive food production. Realizing the negative effects of intensive food production on water and soil quality, direct payments were granted to farmers in the form of a basic income support based on the number of hectares farmed or number of animals reared. The direct payment (decoupled) means that farmers can produce as much or as little as they want and still receive this subsidy (Potter, 2014). This guaranteed greater freedom to produce according to market demand while at the same time shifting emphasis on to stricter environmental and animal welfare rules which the farmers have to follow to receive the payments (European Commission, 2017).

\section{Subsidy on livestock insurance}

Insurance subsidy is a risk management support to protect farmers against health and death of animals. The governments intervene at several levels to improve farms' resilience with respect to these risks, and subsidized insurance schemes especially in livestock, can be found in many countries (Brazil, Chile, china) (OECD, 2013; pp 27-30). Just like India, the costs of insurance premiums are shared between the central government (about 40\%), local governments (about one third) and the farmers (about 20\%) in China. This is done to subsidize the premium rate for the beneficiaries and make insurance policies more affordable for the vulnerable sections of the population. In India, the Government of India provide insurance subsidy in crop and livestock sector in the form of premium contribution. In 2008-09, total expenditure on these schemes were Rs 771 crores; out of which about 0.01 per cent (around Rs 8 crores) was spent on livestock and sheep insurance (Choudhury and Srinivasan, 2011, pp 44).

\section{Extent of subsidy}

As far as the data on amount of subsidy extended to livestock sector is concerned, there is limited information available world over. Nevertheless, there are good amount of studies on agriculture subsidies. In 2012, agricultural subsidies totaled an estimated $\$ 486$ billion in the top 21 food-producing countries in the world. These countries - the members of the Organisation for Economic Co-operation and Development (OECD) and seven other countries (Brazil, China, Indonesia, Kazakhstan, Russia, South Africa, and Ukraine) — are responsible for almost 80 percent of global agricultural value added in the world (OECD, 2013). The study observed that agricultural subsidies are not equally distributed around the globe. Asia spends more than the rest of the world combined. Of the countries studied by the OECD, 94 per cent of subsidies were spent by Asia, Europe, and North America-leaving only 6 per cent for the rest of the world. China pays farmers an unparalleled $\$ 165$ billion. Significant subsidies are also provided by Japan ( $\$ 65$ billion), Indonesia ( $\$ 28$ billion), and South Korea ( $\$ 20$ billion). Europe contributes a great deal to agricultural subsidies due in large part to the Common Agricultural Policy (CAP) of the European Union (EU). At over $\$ 50$ billion, CAP subsidies accounted for roughly 44 percent of the entire budget of the EU in 2011. EU also provides price supports, in which governments keep domestic crop prices artificially high to give farmers a further incentive at the expense of the consumer. Including these price supports, the EU spent over $\$ 106$ billion on agricultural subsidies in total. Direct payments 
are the cornerstone of the EU CAP and account for $\$ 40$ billion of its $\$ 50$ billion budget. North America provides almost $\$ 45$ billion in subsidies, with the United States spending just over $\$ 30$ billion and Canada and Mexico spending $\$ 7.5$ billion and $\$ 7$ billion, respectively. The livestock sector continues to be a major beneficiary of direct payments, particularly in the grazing livestock sector where direct payments represent approximately $55 \%$ of income for EU farmers as a whole (Baldock \& Mottershead, 2017). In England, the corresponding figure was $69 \%$, with direct payments almost equaling the net farm business income of the non-dairy grazing sector as a whole (Defra 2016). The per hectare estimates of subsidies in agriculture mainly on fertilizers, electricity and irrigation were estimated to be $\$ 35$ in Japan followed by USA $(\$ 32)$, China ( $\$ 30$ ) whereas it was only $\$ 14$ per hectare of cropped area in India during 2008-09 (Salunkhe \& Deshmukh, 2012).

In India, Srivastava et al., 2003 estimated central budgetary subsidy in terms of unrecovered costs on economic services of animal husbandry and dairy development to the extent of 138 crores in 1998-99 which was 2.95 per cent of the total subsidy in crop husbandry (Rs 4672 crores). The direct allocation of subsidy for different purposes in the animal husbandry and dairying in the country has been estimated by the working groups appointed by the Government of India (GoI) before commencement of the five year plans. One such report (GoI, 2006-07) provided interest subsidy to the extent of Rs 550 crores to lend interest free loan for the purchase of milk processing equipments like milk pooling, testing and cooling equipments. The working group (GoI, 201112) earmarked capital subsidy to private dairies to the extent of Rs 4000 crores in the twelfth five year plan in order to promote processing of milk and milk products. The capital subsidy is provided to private dairies to the extent of 20 per cent of the investment to a ceiling of rupees one crore.

\section{Reforms in targeting subsidy}

Literature also highlights reforms in targets and methods of granting subsidy. In New Zealand (Vitalis, 2007), the agricultural support which was amounted to just $3 \%$ of farm income in 1960 s, became nearly $40 \%$ in the sheep sector alone by 1983 . Taken together, this was equivalent to $4 \%$ of New Zealand's gross domestic product (GDP). The unsustainability of the subsidy programs catalyzed reforms in agricultural support. The New Zealand government moved quickly by abolishing minimum price schemes for wool, beef, sheep meat and dairy products. In addition, tax concessions for farmers were withdrawn. Free government services for farmers were also eliminated (Tyler and Lattimore, 1990). Indirectly, the removal of agricultural subsidies had a profound, generally positive, impact on New Zealand's sustainable development prospects (OECD, 2007).

In the last two decades, the CAP has undergone three major reforms. In 1992 MacSharry reform introduced a shift from price support to direct payments based on cultivated area and the quantity of farmed animals and also contributed to the reduction of intervention prices (Zhu et al. 2012; Folmer et al. 1995; Ingersent et al. 1998). The second reform entitled Agenda 2000 supported implemented direct payments. Intervention prices also continued to decline and these reductions were offset by the introduction of annual direct payments (Zhu et al. 2012; Benjamin et al., 1999). Fischler reform, which was implemented in 2003 further weakened the link between subsidies and production by introducing the single payment scheme, which separates the direct payments from production (Swinbank and Daugbjerg, 2006). CAP reforms have undergone a long process from price support, direct subsidies linked to production to decoupled payments. The results of study by Rizov et al., 2012 revealed that the decoupled payments are less distortive and enhance productivity which is consistent with the WTO priorities. The direct payment targeted towards public goods and particularly social and environment benefits has gained ground in the CAP in recent years, with thirty per cent of the Pillar I budget being devoted to greening measures since 2014 (Baldock \& Mottershead, 2017).

\section{Implications of subsidy}

Subsidies may either increase or decrease productivity and thus the net effect may be either positive or negative. The negative impact of subsidies on productivity may result from allocative and technical efficiency losses due to distortions in production structure and factor use, and the shift of subsidies to less productive enterprises. The positive impact of subsidies may be due to investment-induced productivity gains caused by interactions of credit and risk attitudes with subsidies (subsidyinduced credit access, lower cost of borrowing, reduction in risk aversion, increase in productive investment) (Rizov et al., 2012). There are a few studies that have estimated the net effect of subsidy.

\section{Impact on production and holding size}

As discussed in the previous sections, like crops, subsidy in livestock sector was intended to increase the use of inputs, ensure rise in income of the farmers through price support and increase supply of livestock products in the market. The effect of subsidy can be better understood while analyzing its removal. In Maxico, subsidies given on feed to offset some of the higher input costs were gradually eliminated during 1995-1999 both for beef and pig meat production which led to reduction in meat production in both the cases (OECD, 2007). Similarly, the removal of the fodder subsidy in Jordan resulted into selling off around half of their flock and consequently, there has been a rise in disease among livestock as well as higher prices for consumers (Jetter, 2008). Lorent et al. (2009) modeled CAP subsidies allocation to sheep and goat breeders in Crete to conclude that it induced individual flock-size to a point causing land-use changes leading to the risk of increasing soil erosion. Farmers who 
increased their flocks to capture maximize CAP subsidies became more sensitive and less adaptive to adverse price changes in agricultural commodities, pushing some of them temporarily into unprofitable situations.

Market price support and deficiency payments are two very important instruments in agricultural policy; however, they belong to two different support regimes. Market price support operates in the so-called high price system and is financed by consumers, while deficiency payments operate in the so-called low price system and are financed by taxpayers. In the high price system, support is given mainly by means of import regulations, which ensure a relatively high domestic price. In the low price system, support is given by means of direct support, while market prices are left undistorted at, or close to, world market level. The two different support systems have very different implications for agricultural production, financing, markets, and other aspects; still, there is an income transfer to agriculture in both systems (Hansen, 2011). During the last decades, the composition of agricultural support has changed significantly. Market price support has decreased, and direct support has increased.

\section{Environment effects of livestock subsidy}

In developed countries, demand for livestock is stagnating and many production systems are increasing their efficiency and environment sustainability. The production system in future will be affected by competition for natural resources particularly land and water, competition between food and feed and by the need to operate in a carbon-constrained economy. There is considerable uncertainty as to how these factors will play out in different regions of the world in the coming decades (Thornton, 2010). The link between subsidies and their adverse effects on sustainable development, specifically the environmental effects, has been recognized by the research community for many years. Such support can, however, have negative effects that may be unforeseen or even ignored in the policy making process. Fuel tax rebates stimulate the use of fossil fuels, support for commercial fishing can lead to the overexploitation of fish stocks and agricultural support can lead to an overuse of pesticides and fertilizers. By the mid to late 1980s and thereafter, researchers were calling attention to the deleterious effects that subsidies were having on, for instance, energy demand (Kosmo, 1987; Larson \& Shaw, 1992; ), the depletion of marine fish stocks (FAO, 1992), and soil degradation (Singh, 2009), agricultural pollution and deforestation (Reichelderfer, 1989; Tobey \& Reinert, 1991; Anderson, 1992; Runge, 1996). There are no reliable estimates of the value of subsidies which have environmentally harmful effects (OECD, 2005)). Typically imprecise value ranges anywhere from $\$ 500$ billion to $\$ 2000$ billion a year which includes nonagricultural subsidies, like support for coal and fishing. Extrapolating data for environmentally harmful agricultural subsidies is difficult but not impossible. One reasonably reliable estimate for the late 1990 s is that OECD country subsidies to agriculture that were environmentally harmful averaged in excess of $\$ 300$ billion per annum (Van Beers \& de Moor, 2001).

In the context of the mounting evidence, it is perhaps not surprising that over the past two decades, there has been a growing acknowledgement by governments of the environmental harm that could arise from subsidies (Steenblik, 2003). As a consequence, many countries have committed themselves to reform subsidies that may eliminate subsidies having negatively effect on environment and agro-biodiversity (Convention on Biodiversity, 1992; Salunkhe and Deshmukh, 2014).

\section{Conclusions}

Information on subsidy targeted directly on livestock is limited and in the same way, the studies reviewed its implications were constrained. The paper summarized some of the anecdote observes from available literature on livestock subsidy in the selective areas.

Applying a concept of livestock production systems lies in its usefulness for livestock development. In these systems, similar practices and circumstances followed for whom a given recommendation would be broadly appropriate. The numerous variables has been used to identify the homogenous livestock production systems but still it is difficult to have a classification which characterize each and every livestock system because of wide variability in breed, feed, practices and the agro-climatic conditions. A comprehensive exercise on classification of livestock systems is the one conducted by Sere and Steinfeld (1996). This classification was further improved by considering the additional criteria of commercialization or intensification of production (Teufel et al., 2010). From dairying point of view, the mixed rainfed temperate and tropical highlands system was adjudged the most important which produces more than half (55.5 per cent) of total milk production from all considered species and 62.6 per cent of cow milk production. However, there are continuous changes taking place in the structure of livestock production system. The most important in these were intensification and landless (industrial) production which is considered to be good from economic point of view but does not address animal welfare issues.

In the process of development, the livestock sector has been provided different kind of incentives in the form of subsidy to achieve certain objectives in mind, for instance, to boost production, reduce high cost of production, technology adoption. In order to do so, subsidy has been provided on investment, purchase of animals and feed. Insurance subsidy is a risk management support to protect farmers against health and death of animals. Like India, the governments in different countries (Brazil, Chile, China) provide subsidy on premium of livestock insurance. In India, Choudhury and Srinivasan, 2011 estimated an expenditure of eight crores $(0.01$ per cent of 
agriculture subsidy) on livestock and sheep insurance in 200809.

The continuous reforms are taking place in granting subsidy to agriculture and livestock sector. In 2012, agricultural subsidies totaled an estimated $\$ 486$ billion in the top 21 food-producing countries in the world. The countries in European Union (EU) and New Zealand have made remarkable reforms in the type and method of granting subsidy. The latest reform in this process is the direct payment decoupled with production which ensures minimum income to the farmer and has less adverse effects on environment. A study by Rizov et al., 2012 observed that the decoupled payments are less distortive and enhance productivity which is consistent with the WTO agenda.

Implications of subsidy are manifold- short and long term. In short term, many studies have revealed immediate effect on increase in the size of holding, use of inputs and production. In the same way, the removal of subsidy has resulted into decrease in meat production and selling of flock. It has been realized that the kind of effects on agricultural production, financing, markets and other aspects differs the way subsidy is extended (price support or direct payments). There is no doubt that subsidies have well served its short term objectives, nevertheless, it has had adverse effects on environment and economic efficiency in the long run such as over-exploitation of fish stock, grazing lands and soil degradation. An imprecise estimate of subsidies which have environmentally harmful effects (OECD, 1998; OECD, 2001; OECD, 2005) has been put $\$ 500$ billion to $\$ 2000$ billion a year. With the passage of time, the governments are becoming aware of its adverse effects and attempts are being made to eliminate such subsidies as the international commitments to reduce subsidies that harm the environment, are growing. At the same time, one has to keep in mind that subsidies once in place are usually extremely hard to eliminate because of various economic and political reasons.

After reviewing the literature on livestock subsidy and its impact, still there are numerous gaps in the knowledge on the topics, a few of which the paper highlights in order to encourage future studies and these are (1) whether the livestock subsidy has any relationship (positive or negative with the status of livestock development in an economy; (2) how to target subsidy so that it has more socio-economic benefits and less adverse environmental effects?, (3) how frequently subsidy targets should be reviewed?, and (4) who benefits from a particular livestock subsidy and how- industry, farmer or the consumer?

\section{References}

Anderson K (1992) Effects on the environment and welfare of liberalising world trade: The cases of coal and food. In The greening of world trade issues, Edited by: Anderson, K and Blackhurst, R. 47-61. Michigan: University of Michigan Press.
Baldock D, Mottershead DH (2017) Towards an integrated approach to livestock farming, sustainable diets and the environment: challenges for the Common Agricultural Policy and the UK, Institute for European Environmental Policy, London

Benjamin C, Gohin A, Guyomard H (1999) The future of the European Union dairy policy. Canadian Journal of Agricultural Economics 47(5): 91-101

Bingsheng K (2002) perspectives and strategies for the livestock sector in China over the next three decades. Food and Agriculture Organization Livestock Information and Policy Branch, AGAL. Livestock Policy Discussion Paper No. 7.

Byerlee D, Collinson M, Perrin R, Winklemann D, Biggs S, Moscardi E, Martinez J, Harrington L, Benjamin A (1980) Planning Technologies Appropriate to Farmers: Concepts and Procedures. CIMMYT El Batan Mexico:71

Choudhury M, Srinivasan R (2011) A Study on Insurance Schemes of Government of India (Final Report). National Institute of Public Finance and Policy, New Delhi.

Jetter, C (2008) An Assessment of Subsidy Removal Effects on and Future Sustainability for Livestock Sector of in the Northern Jordanian Badia. Independent Study Project (ISP) Collection. https:// digitalcollections.sit.edu/isp_collection/7

Defra (2016) Farm income by type of farm in England, Farm Business Stastics, available at https://www.gov.uk/government/collections/ farm-business-survey

Drucker A, Bergeron E, Lemke U, Thuy L, Zãjrate A (2006) Identification and Quantification of Subsidies Relevant to the Production of Local and Imported Pig Breeds in Vietnam. Tropical Animal Health and Production 38: 305-322

EC (European Commission) (2017) CAP Explained: Direct payments for farmers 2015-2019. Agriculture and rural development (May, 2017): page $1-12$

FAO. (1992) Marine fisheries and the Law of the Sea: A decade of change, Rome: Food and Agriculture Organisation. Fisheries Circular No. $853 \mathrm{FID} / \mathrm{C} 853$

FAO. (2001) International plan of action to prevent, deter and eliminate illegal, unreported and unregulated fishing, Rome: Food and Agriculture Organisation.

Folmer C, Keyzer MA, Merbis MD, Stolwijk HJJ, Veenendaal PJJ (1995) The Common Agricultural Policy Beyond the MacSharry Reform. Contributions to Economic Analysis. North-Holland Elsevier, Amsterdam

Fonteh FA, Mubiru S, Tibayungwa F, Lammers W (2005) System analysis of peri-urban smallholder dairy farming in the Lake Crescent Region of Uganda. Livestock Research for Rural Development. 17: 79

GoI (2006-07) Report of the working group on animal husbandry and dairying, $11^{\text {th }}$ Five Year Plan (2007-12), Planning Commission, New Delhi

GoI (2011-12) Report of the working group on animal husbandry and dairying, $12^{\text {th }}$ Five Year Plan (2012-17), Planning Commission, New Delhi

Hansen HO (2011) Policy Schemes and trade in Dairy products: Agricultural Policy Schemes: Price and Support Systems in Agricultural Policy. Encyclopedia of Dairy Sciences. 286-294

Hemme T, Otte J (2010) Status of and Prospects for Smallholder Milk Production - A Global Perspective. Food and Agricultural Organization of United Nations, Rome

Ingersent KA, Rayner AJ, and Hine RC (1998) The Reform of the Common Agricultural Policy. St. Martin's Press, New York

Jahnke H (1982) Livestock production systems and livestock development in Tropical Africa. Kieler Wissenschaftsverlag Vauk, Kiel, Germany

Kosmo M (1987) Money to burn? The high costs of energy subsidies, Washington, DC: World Resources Institute 
Larsen B, Shaw A (1992) World fossil fuel subsidies and global carbon emissions, Washington, DC: World Bank. Policy Research Working Paper Series, No. 1002

Lorent H, Sonnenschein R, Tsiourlis GM, Hostert P, Lambin E (2009) Livestock subsidies and rangeland degradation in central Crete. Ecology and Society 14(2): 41. URL: http:// www.ecologyandsociety.org/vol14/iss2/art41/

OECD (1998) Improving the environment through reducing subsidies, Paris: OECD

OECD (2001) Environmental effects of liberalising fossil fuels trade: Results from the OECD green model, Paris: OECD.

OECD (2001) Market Effects of Crop Support Measures, OECD, Paris

OECD (2005) Environmentally harmful subsidies, Paris: OECD

OECD (2007) Agricultural and Fisheries Policies in Maxico: Recent achievements, continuing the reform agenda. Page 130-131

OECD (2013) Agricultural Policy Monitoring and Evaluation 2013: OECD Countries and Emerging Economies, OECD Publishing. http:// dx.doi.org/10.1787/agr_pol-2013-en: pp 27-30

Potter G (2014) Agricultural Subsidies Remain a Staple in the Industrial World. Vitalsigns, Worldwatch Institute, Washington, USA

Reichelderfer K (1989) Environmental protection and agricultural support: Are trade-offs necessary? National Center for Food and Agricultural Policy Discussion Paper Series FAP89-03, Washington, DC: Resources for the Future.

Rizov M, Polrivcak J, Ciaian P (2012) CAP subsidies and productivity of the EU farms. Selected Poster prepared for presentation at the International Association of Agricultural Economists (IAAE) Triennial Conference, Foz do Iguaçu, Brazil, 18-24 August, 2012

Robinson T, Franceschini G, Kruska R, Chiozza F, Notenbaert A, Cecchi G, Herrero M, Epprecht M, Fritz S, You L, Conchedda G, See L (2011) Global livestock production systems. FAO and ILRI. 152

Runge CF (1996) Environmental impacts of agriculture and forestry subsidies". In OECD, subsidies and the environment: Exploring the linkages, 139-161. Paris: OECD

Ruthenberg H (1980). Farmings systems of the tropics. Oxford: Clarendon Press

Salunkhe H, Deshmush B (2014) Impact of Subsidy on Agriculture Sector in India- An Analytical Study. International Journal of Agricultural Science and Research 4 (2): 9-16

Salunkhe HA, Deshmukh BB (2012) The overview of Government subsidies to agriculture sector in India. IOSR Journal of Agriculture and Veterinary Science. 1(5): 43-47

Sere C, Steinfeld H (1996) World Livestock Production Systems: Current Status, Issues and Trends. Animal Production and Health Paper 127: 82

Singh S (2009) Agricultural Machinery Industry in India: A Growth Market structure and business strategy, CMA Publication No.230, Center for management agriculture (CMA) \& Indian Institute of Management Ahmadabad (IIMA) Ahmadabad, PP-37.

Srivastava, DK, Rao CB (2003) Government Subsidies in India: Issues and Approach. In Edgardo M. Favoro and Ashok K. Lahiri (eds.) Fiscal Policies and Sustainable Growth in India. Oxford University Press: New Delhi.

Staal SJ, Chegel, Kenyanjui M, Kimari A, Lukuyu B, Njubi D, Owango M, Tanner J, Thorpe W, Wambugu M (1998) Characterisation of Dairy Systems Supplying the Nairobi Milk Market: A Pilot Survey in Kiambu District for the Identification of Target Groups of Producers. KARI/ MoA /ILRI Collaborative Research Project Report, Ministry of Agriculture, Livestock Production Department, Kiambu, Kenya

Staal SJ, Owango M, Muriuki H, Kenyanjui M, Lukuyu B, Njoroge L, Njubi D, Baltenweck I, Musembi F, Bwana O, Muriuki K, Gichungu G, Omore A, Thorpe W (2001) Dairy systems characterisation of the greater Nairobi milk shed, SDP Research Report Smallholder Dairy (R\&D) Project Report, Nariobi, Kenya

Steenblik, RP (2003) Subsidy measurement and classification: Developing a common framework. In Environmentally harmful subsidies: Policy issues and challenges, 101-141. Paris: OECD

Steinfeld H, Mäki-Hokkonen J (1995) A classification of livestock production systems. World Animal Review 84/85: 83-94

Steinfeld H, Wassenaar T, Jutzi S (2006) Livestock production systems in developing countries: status, drivers, trends. Revue scientifique et technique 25 (2): 505-516

Sugiyama M, Iddamalgoda A, Oguri K, Kamiya N (2003) Development of Livestock Sector in Asia: An Analysis of Present Situation of Livestock Sector and Its Importance for Future Development

Swinbank A, Daugbjerg C (2006) The 2003 CAP reform: Accommodating WTO pressures. Comparative European Politics 4(1): 47-64

Teufel N, Markemann B, Kaufmann A, Zarate V andOtte J (2010) Livestock Production Systems in South Asia and the Greater Mekong Sub-Region. Pro-Poor Livestock Initiative, working paper no. 48. Food and Agriculture Organization, Animal Production and Health Division Viale delle Terme di Caracalla 00153 Rome, Italy

Thorton P (2010) Livestock production: recent trends, future prospects. Philosophical Transactions of the Royal Society B: Biological Sciences 365: 2853-2867

Tobey J, Reinert K (1991) The effects of domestic agricultural policy reform on environmental quality. Journal of Agricultural Economics and Research 43: 20-28

Tyler L, Lattimore R (1990) Assistance to agriculture. In Farming without subsidies: New Zealand's recent experience, Edited by: Sandrey, R, and Reynolds, R. 60-79. Wellington: Government Print Books and Ministry of Agriculture and Fisheries

UN (United Nations) (2014) World economic situations and prospects. Development Policy and Analysis Division (DPAD), Department of Economic and Social Affairs of the United Nations Secretariat (UN/DESA).

USDA (2016) Turkish Livestock Support and Subsidies Update 2016, Global Agricultural information network, Report TR6031, UDSDA Foreign Agricultural Service, Ankara

Van Beers C, De Moor A (2001) Public subsidies and policy failures: How subsidies distort the natural environment, equity and trade and how to reform them, Cheltenham: Edward Elgar

Vitalis V (2007) Agricultural subsidy reform and its implications for sustainable development: the New Zealand experience. Environmental Sciences 4(1):21-40

Wakhungu, JW (2001) Dairy cattle breeding policy for Kenya small holders: An evaluation based on a demographic stationary state productivity model. Ph.D. thesis, University of Nairobi: pp189

Williams TO (1994) Identifying target groups for livestock improvement research: The classification of sedentary livestock producers in western Niger. Agricultural Systems 46 (2): 227-237

Wilson T (1994) Integrated Livestock and Crops for Sustainable Use and Development of Tropical Agricultural Systems. AGSP-FAO: 84-92

Zhaohai B, Wenqi M, Lin M, Gerard V, Wei L, Havlik, Z, Oenema P, Lee O, Michael RF, Zhang, Zhang F (2018) China's livestock transition: Driving forces, impacts, and consequences. Science Advances 4(7): $1-11$

Zhu X, Demeter RM, Lansink AO (2012) Technical efficiency and productivity differentials of dairy farms in three EU countries: the role of CAP subsidies. Agricultural Economics Review 13(1): 66-92 